\title{
THE IMPACT OF OUTCOME-BASED PHILOSOPHY AND PRACTICE ON A GROUP OF EFL TEACHERS' BELIEFS AND ACTIONS
}

\author{
NGUYEN TRUONG SA \\ Industrial University of Ho Chi Minh City \\ nguyentruongsa@iuh.edu.vn
}

\begin{abstract}
This case study aims at identifying the beliefs and actions held by a group of teacher teaching English in a context with particular outcome-based philosophy and practices, high demands from stakeholders and standardized procedures of quality assurance. Questionnaire, semi-structured and stimulated recall interviews were employed to collect data from a group of 35 lecturers teaching different courses in a Bachelor of English language program accredited by AUN-QA. Microsoft Excel was employed to analyze the quantitative data; Semantic content analysis and the NVIVO software were used to transcribe, code, and segment the qualitative data to then establish categories depicted what participants believed and performed regarding teaching and learning. Different form previous studies, two groups of beliefs were generated namely beliefs about contextual factors that formulate the teaching and beliefs about contextual factors that affect the teaching. The results showed that the strongest factors that shaped the teachers' beliefs and action in a course were the teaching philosophy of the institution and the expected learning outcomes of the course they taught. Meanwhile, the contextual factors that previously-believed to significantly affect teachers actions were much less influential. Moreover, a teacher in an outcome-based teaching context also performed the role of a quality assurance manager at course level and acting actively to contribute to the achievement of the organizational objectives and missions.
\end{abstract}

Key words: outcome-based education, teachers' beliefs and actions

\section{INTRODUCTION}

Teachers' beliefs and experience as a learners and a teacher direct the ways they conceptualize teaching and influence the ways they teach. In the field of foreign language teaching, cognitive approach to English as a foreign language (EFL) classroom research often concentrate on the beliefs of the teachers as central causes to events in classrooms (Borg, 2006; Davis, 2003; Donohue, 2003; Mohamed, 2006). Meanwhile, contextual approach mainly examined how students' expectations, learning styles, or physical condition of the classroom, or cultural expectation affect teachers' ways of teaching in class (Faour, 2003; Phillips, 2009; Five and Buehl, 2012; Cuayahuitl and Carranza, 2015; Sun, 2017; Mai, 2017). However, the shift towards outcome-based education (OBE) recently in Vietnam is more strongly influenced by stakeholder expectations that higher education must provide locally and globally competitive graduates to contribute to local, national and global development. OBE, in both educational philosophy and practice, provides a framework for focusing and organizing the curriculum around predetermined and clearly defined student learning outcomes. It has been viewed as a significant paradigm shift in education which focuses on what students know and can do as a result of a learning experience or acquiring a degree (Tam, 2014; Biggs, 2014). When learning outcomes are stated in clear and specific terms, there is a strictly alignment of curriculum and pedagogy such as module design and delivery as well as assessment tasks and activities with the intended outcomes (Sin, 2014; Dobbins, Brooks, Scott, Rawlinson \& Norman, 2016). This approach to teaching makes it possible for teachers to focus on what outcomes students are expected to achieve and provide them with the assistance to do so. As teachers teaching practices are often driven and influenced by internal and social factors. In order to understand the reason of a specific teacher action, it is vitally important to comprehend the underlying idea behind it (Sakui, 2004). In response to how the contemporary trend of OBE in education might affect what teachers believe and do, this study examined the case of a group of EFL teachers to find out the impact of OBE philosophy and practice on their beliefs and actions. 


\section{LITERATURE REVIEW}

\subsection{Belief, action, and context}

Action: Action, as being used it in this study, is an umbrella term to cover both conscious and goal-directed behaviors derived from experience following training or self-development (Dickinson, 1985; Nardi, 1996), and unreflective automatic behaviors learned through socialization (Ajzen, 1991; Leinhardt \& Greeno, 1991).

Belief: Pajares (1992) defined belief as an "individual's judgment of the truth or falsity of a proposition, a judgment that can only be inferred from a collective understanding of what human beings say, intend, and do" (p. 316). As beliefs should be inferred from what a person says and does (Borg, 2001, 2006; Woods, 1996), a teacher's belief is defined in this study as what a teacher thinks, knows, believes and performs while teaching.

\section{Beliefs and actions}

According to Bandura (1997), beliefs are the best indicators of the decisions people make and people tend to act according to their beliefs. Williams and Burden (1997) affirmed that even if a person acts spontaneously or unconsciously, "such actions are nevertheless prompted by a deep-rooted belief that may never have been articulated or made explicit" (p. 56). When we make up our mind what to do, based on beliefs we form an intention, with such intention we move to act (Aune, 1990). Noticeably, a person's beliefs both shape and are shaped by actions (Barcelos, 2003; Borg, 2006; Haney et al., 2002; Nardi, 1996), or more exactly, by a person's assessment of the result of his/her actions (Haney et al., 2002). From these evaluations, a person may adjust and adapt his/her actions, change his/her attitudes, and/or beliefs. Barcelos (2000) claimed that it is not a cause-effect relationship but a relationship where understanding contextual constraints helps understanding beliefs.

\section{Contextual factors, beliefs, and actions in research in the field of language teaching}

Language teaching can be seen as a decision-making process; teachers interpret a teaching situation in the light of their beliefs about the learning and teaching of what they consider second language learning consists of; the result of this interpretation is what the teacher plans for and attempts to create in the classroom (Mak, 2011; Borg, 2015; Ortega \& Cruz, 2016).

In the literature, a number of research studies have investigated the contextual constraints on the language teachers. Golombek (1998) found that teachers' beliefs informed the teachers' practices by filtering their experience so that they reconstructed it and acted according to the demand of a teaching situation and by giving physical form to their practices. Barkhuizen (2008) provides the rationale for a context-sensitive approach to teaching by suggesting that "teachers teach best and students learn best in situations that are compatible with their backgrounds, beliefs and expectations" (p.233). Bax (2003) noted that the first priority is the learning context, and the first step is to identify key aspects of that context before deciding what and how to teach in any given class. In 2011, Mak found that teachers perceived need to survive and adapt to the institutional teaching cultures, the past learning experience, the tension between different beliefs, some culturally influenced beliefs, and exposure to teaching cultures and models of language teaching.

A wide range of contextual factors were also identified and/or proposed for better management of the teaching and learning. Class size, motivation and proficiency level of students, course-book, exams, syllabus, time, facilities, materials, and physical resources and condition were some of the most identified common factors (Richards \& Pennington, 1998; Faour, 2003; Bax, 2003; Phillips, 2009; Jamalzadeh \& Shahsavar, 2015; Cuayahuitl \& Carranza, 2016; Sun, 2017). Schools' socioeconomic status, local conditions, the classroom culture, school culture, and national culture can also affect teachers' beliefs and practices significantly (Faour, 2003; Bax, 2003). According to Bax (2003), Cuayahuitl and Carranza (2016) and Altınsoy and Okan (2017), classroom culture or institutional context includes internal regulations, group dynamics, group motivation, classroom environment, school environment; local culture includes regional differences, status of teacher and students in community, attitude and behavior of parents, local environment; and national culture is political context, religious context, and social context.

\subsection{OBE and English language teaching}

There are many definitions of Outcomes-Based Education (OBE) stated by different researchers in the field. The common theme shared among the scholars is that means focusing and organizing an education 
system around what is essential for all learners to be able to succeed at the end of their learning experiences. This means starting with a SMART (specific, measurable, attainable, realistic, timely) outcome of what is important for learners to be able to attain, then organizing curriculum, teaching, and assessment to make sure this learning ultimately happens (Malan, 2000; Borsoto et.al., 2014; Ortega \& Cruz, 2016; Hồ \& Nguyễn, 2018). Thus, OBE is a kind of informed teaching and learning; learners know beforehand what they are going to learn and how they are going to learn what they learn, and the teachers know what their students are expected to learn and how best they will be able to use the learnt experience in doing what they are expected to do at the end of the learning. OBE is, therefore, a learner-centered approach and an outcomes-oriented curriculum model. OBE is often described as involving "a fundamental philosophical shift in curriculum policy, practice and evaluation because of its unrelenting focus on what students have learned rather than on what systems and schools have provided and teachers have taught" (Willis \& Kissane, 1995, 2).

Outcome-based philosophy in a school or education system is defined as a belief of the whole system that there are certain things that all students should learn as a result of learning, that the school is prepared to say to public what these things are, and that it is prepared to stand accountable in terms of them (Willis \& Kissane, 1995). According to Willis and Kissane (1995), people may be drawn to outcome-based philosophy for quite different reasons. Some consider that OBE enhances what is actually taught to students, others see OBE as a means of ensuring that all students have access to and succeed with high quality outcomes, and still others that OBE offers an improved approach to accountability and to the distribution of responsibilities within a school system. As a result, OBE practice, involves the premise that decisions about what and how to teach should be driven by the outcomes the stakeholders would like students to perform at the end of their educational experience; teaching and learning are enhanced by the clear articulation of these expected outcomes and a commitment by the whole school community to align teaching and assessment towards these outcomes (Willis \& Kissane, 1995; Ortega and Cruz, 2016).

According to AUN-QA Framework (version 3), an OBE curriculum must ensure that:

- The expected learning outcomes have been clearly formulated and aligned with the vision and missions of the university;

- The expected learning outcomes clearly reflect the requirements of the stakeholders;

- The curriculum is designed based on constructive alignment with the expected learning outcomes;

- The curriculum is designed based on constructive alignment with the expected learning outcomes;

- The contribution made by each course to achieve the expected learning outcomes is clear;

- Teaching and learning activities are constructively aligned to the achievement of the expected learning outcomes;

- The student assessment is constructively aligned to the achievement of the expected learning outcomes;

- The educational philosophy, programme and course specifications are communicated and made available to the stakeholders.

In the field research in English language teaching, compared to quality assurance perspectives, OBE seems to be much less transparent. According to Kilfoil and Van der Walt (1997) and Thobedi (2005), the use of the OBE approach in classrooms aims to develop learners' competency and the ability to use English in authentic situations, such as during formal and informal conversations. Schlebusch and Thobedi (2004) also pointed out that educators and learners in the OBE English classroom are involved in the communicative process when using strategies such as direct instruction, discussion, group work, cooperative learning, problem solving, and learner research and performance activities effectively. To make conclusion for the impact of OBE on teachers, Khoshsima and Toroujeni (2017) and Mai (2017) argued that many contextual aspects, such as teachers' and students' perspectives on English language teaching and learning in practice, cultural expectations and distinct features of the English environment at the local have a significant impact on the implementation of communicative teaching method in the classroom.

So far, the literature has much concentrated on the effect of education and training, students, and the physical condition of the context on teachers' beliefs and actions. It is significant to examine how their beliefs and actions are formulated in a context with educational philosophy and practices shaped by OBE, 
high demands form stakeholders and standardized procedures of quality assurance. Accordingly, in such a particular context, this study examined the two following questions:

1. How do OBE contextual factors affect a group of EFL teachers' beliefs about language teaching?

2. How do these beliefs shape their actions when teaching in class?

\section{RESEARCH DESIGN}

\subsection{The fieldwork of the study}

As an educational body paving its path toward excellence during the past 60 years of development, the university in this study is one of the biggest educational and training institutions in Vietnam.

The university's vision: Becoming a key university of the nation; leading in the development among the institution governed by Ministry of Industry and Trade; being ranked among the top ten Vietnam leading universities in terms of application-based development, and being as qualified as other regional developed countries in terms of training high-quality human resources.

The university's mission: Providing high-quality human resource with high professional and practical skills in terms of economics, engineering, science research, and technology transfer to create physical and mental values serving the socio-economic development of the industry and the country efficiently.

The educational philosophy of the university: Quality, sustainable development, international integration. Among the three aspects being emphasized, quality is the premier factor which also helps foster sustainable development as well as internal integration. This statement of philosophy has affected and been involved in every aspect of the education from training to assessment, research or management in the university.

Missions of the faculty: Training and enhancing human resources with sufficient foreign language abilities and life skills, raising the students' awareness of self-study and research in order to meet the requirements of the society; Contributing to the development of the university as well as the economic, socio-cultural development of the local area and the country.

3.2. The training program: Bachelor in English language

Quality assurance framework: AUN-QA

The BEL program started its quality development under the AUN-QA standard from 2016; it is certified to meet all of the quality framework criteria in 2019 and received AUN-QA certification in the same year.

The program learning outcomes (PLOs): The PLOs of the BEL program, which expected the students to be able to attain at the time of graduation, are:

- PLO 1: Utilize four English macro skills fluently and effectively for social, academic and professional purposes

- PLO 2: Demonstrate knowledge of English linguistics, language education, literature and culture in professional and academic tasks

- PLO 3: Perform professional tasks with the use of English in educational, social, business and service environments

- PLO 4: Integrate problem-solving skills into academic and professional tasks

- PLO 5: Engage in life-long learning process

- PLO 6: Demonstrate an awareness of academic and professional ethics

- PLO 7: Function effectively as a team member on multi-tasking and multi-disciplinary issues

The seven PLOs are intended to serve the education of graduates who possess the knowledge, skills, and attitudes that are demanded in our current changing society. In order to improve the quality of the program towards outcome-based education approach, feedback from various stakeholders has been taken into consideration when formulating the PLOs and during the training process. The internal stakeholders include the university administration, academic staff involved in the program, undergraduate students taking part in the program and alumni. Meanwhile, the Vietnamese government, MOET, potential and current employers, experts in the field of education and language education and international economic, educational and cultural organizations are identified as external stakeholders.

The curriculum: The curriculum is designed with special attention paid to its constructive alignment with the PLOs. The curriculum of BEL includes components of generic, foundation, specialized and professional courses, each of which is designed to aim at the balance of theoretical, empirical knowledge, skills and attitudes. Each PLO is intended to be achieved thanks to a number of courses with the hierarchy ranging 
from easy to difficult. How the contribution is made is stated comprehensively in each course specification, especially through the teaching, learning and assessment activities.

\subsection{The participants}

All of the lecturers participated in this study hold Master in TESOL and had more than 15-year experience in various courses for university-age student and students of BEL program. They also had 3 years of experience in teaching the courses under AUN-QA framework with outcome-based educational philosophy and practice.

\subsection{Research methods and procedures}

To investigate teachers' and students' beliefs, it is not only necessary to let individuals construct their beliefs through discourse (Kalaja: 2003; Dufva: 2003; Kramsch: 2003), it is also necessary to examine both stated beliefs and beliefs in actions, and differentiate between "blind" and "reasoned" beliefs. Consequently, inferring beliefs from classroom actions (Barcelos: 2003; Nespor: 1985) and from interviews (Wenden: 1986a, 1987; Peacock: 1998a) can help to capture the beliefs from the participants' views and practices in specific and natural contexts. Due to the nature of beliefs, and the research questions, and in order to track beliefs from other cognitive factors, an interpretivist paradigm with two qualitative methods of semistructured interview and stimulated recall interview and a qualitative method with survey were adopted.

The survey: The purpose of the researcher was creating a tool to track beliefs that emerge from beliefs holders' reasons for, and evaluations and judgments on their daily activities and actions. Consequently, a survey was developed by the researcher basing on both the contextual factors that emerged from the literature and concepts driven from AUN-QA framework. Validity and reliability of the tool were discussed and checked with 2 experts in the field of quality assurance in education and 3 experts in the field of English language teaching. The finalized and confirmed tool was an 18-questions scale containing both Likert-scale questions and open-ended questions written in Vietnamese language (Appendix). The questionnaire was introduced to the lecturers teaching in the program and 35 of responses were collected at the beginning of the semester.

Semi-structured interview: This method provides flexible protocol with a list of initial questions to guide the interview and supplemented by follow-up questions, probes and comments. To maintain un-bias interviews and to ensure that the researcher was able to collect the most intensive and informative data, questions for the interviews were written around both physical and psychological contexts such as facility, level of proficiency, learning styles, time constraints, class size, and contextual factors related to criteria in AUN-QA framework for program level. The topics taken for the interview questions were also pre-checked and discussed with experts in the field of both quality assurance in higher education and language teaching to make sure that the questions would aimed at eliciting ideas and concepts related to OBE. In the end, questions adopted as an outline guiding the interviews were:

Table 2: Outlined topics for the semi-structured interview

\begin{tabular}{|l|l|}
\hline \multicolumn{1}{|c|}{ Groups of questions } & \multicolumn{1}{c|}{ Planned questions to guide the interviews } \\
\hline $\begin{array}{l}\text { Questions to check how } \\
\text { physical and } \\
\text { psychological } \\
\text { contextual factors affect } \\
\text { the lecturers }\end{array}$ & $\begin{array}{l}\text { Ex: Facility, infrastructure, level of proficiency, learning styles, time constraints, } \\
\text { class size. } \\
\text { Questions: Can you evaluate the [facility] in your class? How would the [facility] } \\
\text { support and/or prevent the effect of your teaching? Why? }\end{array}$ \\
\hline $\begin{array}{l}\text { Questions to examine } \\
\text { whether the vision, } \\
\text { missions and culture of } \\
\text { the institution affect the } \\
\text { lecturers }\end{array}$ & $\begin{array}{l}\text { Would you please clarify again what the strengths of the graduates from the program } \\
\text { teacher in this program, can you evaluate the level of your own impact on those } \\
\text { differences? }\end{array}$ \\
\cline { 2 - 2 } & $\begin{array}{l}\text { What is your core value when teaching? How is it related to the value or philosophy } \\
\text { of your teaching context? }\end{array}$ \\
\hline $\begin{array}{l}\text { Questions to examine } \\
\text { the extent to which the } \\
\text { expected learning } \\
\text { outcomes affect the } \\
\text { lecturers }\end{array}$ & Who influence to most of your decision when teaching? In what ways? \\
\cline { 2 - 2 } & Which ELOs in the BEL are the most important ones? Why? \\
\cline { 2 - 2 } & $\begin{array}{l}\text { Now we turn to the course(s) you are teaching, } \\
\text { What are the students expected to achieve after this course? }\end{array}$ \\
\hline
\end{tabular}




\begin{tabular}{|l|l|}
\hline \multirow{y}{*}{} & $\begin{array}{l}\text { How do these outcomes affect and influence you in each stage of planning, teaching, } \\
\text { and testing? }\end{array}$ \\
\cline { 2 - 3 } & What teaching and/or learning activities you adopt most often? Why? \\
\cline { 2 - 3 } & How do you assess your students? \\
\cline { 2 - 2 } & $\begin{array}{l}\text { What do you expect from your students? (Their role, learning style, autonomy level, } \\
\text { attitude, performance, etc.) }\end{array}$ \\
\hline
\end{tabular}

Eight participants who provided very critical or ambiguous responses in the surveying stage were chosen for in-depth interviews. Each interview was carried out in Vietnamese language in 100 to 120 minutes; the method encourages informants to repeatedly build his/her cognition or part of the cognition by evaluating events, activities, and people related to his/her experience. The aim of the interviews is to discover the underlying reasons that the subjects hold to categorize and classify their stated reasons for their actions when teaching.

Stimulated recall interview is an introspective method that represents "a means of eliciting data through process involved in carrying out a task or activity" (Gass \& Mackey: 2000: 1) by inviting subjects to recall their concurrent cognitive activity when that event was going on (Gass \& Mackey: 2000; Norman: 1983). There were two protocols: observation for the researcher to take notes of the classroom events and teachers' actions and the recall interview for the participants to explain for their noted actions. As this method is quite time-consuming, only 4 lecturers were able to take part in these triangulated procedures.

\subsection{Data analysis}

For qualitative data taken from the questionnaire, the Excel software helped the researcher to analyse and tabulate the responses. After that, adopting the content analysis method (Glaser \& Strauss: 2009; Hsieh \& Shannon: 2005; Seale: 2004), with the help of the NVIVO 9 software, the qualitative data were analysed and coded inductively through a process starting from line-by-line analysis (open coding) to relating the open-codes to build themes/categories of beliefs based on valid inference, interpretation, and inductive reasoning. The data analysis started with reading all data repeatedly to achieve immersion and obtain a sense of the whole. Then, the data was read word by word to derive free codes (or free nodes as named in the NVIVO software) by first highlighting the exact words from the text that appeared to capture key thoughts or concepts. The codes then were sorted into categories based on how different codes were related and linked. These emergent categories were used to organize and group codes into meaningful clusters (or tree nodes). Then, those clusters from the teachers were compared for similarities and differences.

\section{RESULT AND DISCUSSION}

\subsection{How do OBE contextual factors affect the beliefs of EFL teachers about language teaching?}

Table 3 summarizes results analyzed from the Likert-scale data. Based on the number of choice, the CLO and assessment emerged as the most influential factors with $35 / 35$ choices from the respondents. This result strongly correlated to the mean score calculation where the highest scores of 5.20 and 5.14 were counted respectively.

Other OBE-related factors such as PLO and philosophy of the university and personal philosophy were also evaluated as strong influential factors. Meanwhile, factors related to physical contexts and the psychology of the learners were graded as less important. For instant, the mean score for factors such as motivation, attitude, styles was only 3.45 with 19/35 choices, and the score for the availability of necessary facilities and teaching aids was 3.71 with $23 / 35$ choices among the participants. Other factors that were not pre-listed in the survey received very small nomination from the participants with only $12 / 35$ choice and 2.62 mean score.

Table 3: Evaluation from the participants on the influential level of the contextual factors

\begin{tabular}{|c|l|c|c|}
\hline No. & \multicolumn{1}{|c|}{ Contextual factors } & Mean score & Number of choice \\
\hline 1 & The available facilities and teaching aids & 3.71 & $23 / 35$ \\
\hline 2 & Learners' levels of proficiency & 4.51 & $25 / 35$ \\
\hline 3 & Time constraint & 4.31 & $20 / 35$ \\
\hline 4 & $\begin{array}{l}\text { Learners' psychological factors such as motivation, } \\
\text { attitude, styles }\end{array}$ & 3.45 & $19 / 35$ \\
\hline 5 & Course's expected learning outcomes (CLO) & 5.20 & $35 / 35$ \\
\hline
\end{tabular}


OF EFL TEACHERS' BELIEFS AND ACTIONS

\begin{tabular}{|c|l|l|c|}
6 & Program's expected learning outcomes (PLO) & 4.68 & $28 / 35$ \\
\hline 7 & Testing and assessment & 5.14 & $35 / 35$ \\
\hline 8 & The educational philosophy of the university & 5.12 & $26 / 35$ \\
\hline 9 & The personal educational philosophy of the teacher & 5.09 & $24 / 35$ \\
\hline 10 & Other factors & 2.62 & $12 / 35$ \\
\hline
\end{tabular}

In combining the result of the survey and analysis of the qualitative data from the semi-structured interviews, it was noted that instead of physical condition of the class or mental and psychological factors of the students as widely stated in the literature, the most influential contextual factors were the culture of the teaching contexts and the courses' expected learning outcomes. Interestingly, although the interview procedures started with questions related to physical and psychological of the class, the participants' stated beliefs seemed to stick closely to the central concepts driven from OBE. The results showed that the vision, mission, educational philosophy of the university, the expected learning outcomes of training program were stated as the central strongly shaped their beliefs.

Through the triangulated processes of quantitative and qualitative data analysis, two groups of beliefs were generated: beliefs about contextual factors that formulate the teaching and beliefs about contextual factors that affect the teaching.

Beliefs about the contextual factors that formulate and guide the teaching

Personal teaching philosophy: Among the stated contextual factors, the culture of the institution in terms of teaching philosophy emerged as one of most influential factors. Due to the alignment of the philosophy from the institution to department level, each lecturer in the university has also performed this philosophical alignment in their daily teaching. Therefore, the educational philosophy "Quality, Sustainable development, International integration" is also cascaded to individual teaching philosophy of the participants. Due to the underlying meaning conveyed in the philosophy, while being interviewed, the lecturers believed that their teaching must (1) "satisfy the stakeholders' needs at the present time but also in the future, linked to graduates' career and social needs in the field of English language" [L.6, I.2, p.3], and (2) "equip the graduates the ability to work and study towards the current international development trend of the workforce" [L15, I.1, p.2].

Mission of a teacher: Similar to the teaching philosophy, each of the participants of the interviews also, from the vision and mission at the institutional level, developed a personal mission at work, and they strongly believed that the mission is the internal drive for their teaching. The general goal that shared among the participants was "contributing to the attainment of the department's and university's mission" [L.7, I.2, p.4]. However, this common goal was personalized into different stated missions such as:

Lecturer 6: "My mission (in all subjects) is teaching to meet the expected learning outcomes"

Lecturer 7: "The reasons for all of my efforts here is providing excellent teaching"

Lecturers 15, 22: Both of the lecturers believed that their mission is "helping students to be ready for the future" As being confirmed by the lecturer 7 in an interview, the role of this mission is "for me to be clear about my expected roles in the organization, and help me to be confident in decision making when teaching".

The expected learning outcomes and assessment: Under the OBE principle operating in the university, the program expected learning outcomes must be driven from and clearly reflect the requirements of the stakeholders; and the central stakeholders are defined as the students, alumni, employers, and lecturers. After that, the contribution made by each course must help to achieve the program expected program learning outcomes. Learning outcomes of the course are expressed in terms of what students will be able to do and/or perform under as they master the course content. Then, teaching, learning and assessment activities MUST be constructively aligned to the achievement of the course learning outcomes. Therefore, the lecturers must ensure that there is a constructive alignment between teaching and learning activities and assessment and the achievement of the CLOs. As a result, all of the participants strongly believe that the central foundation to guide their planning and teaching is the courses learning outcomes and assessment. Beliefs about the contextual factors that affect the effectiveness of teaching 
Besides the contextual factors that guide and direct the teaching, the participants also admitted that other physical and psychological factors were also influential to the effectiveness of their teaching. For example: among the specified factors, some of the key factors that took much consideration of the lecturers were:

Lecturer 8: Proficiency level of students, course-book

Lecturer 11: Time constrains, facilities, materials, proficiency level of students

Lecturer 19: Physical resources, time constrains

Lecturer 32: Student motivation, classroom environment, proficiency level of students

Interestingly, these factors could be issues for concern to any teacher teaching English around the world. Different from what have been shared widely in the literature about the effect of these physical and psychological factors of the teaching context, results in this study showed evidence that for the lecturers in an OBE teaching context, they should be treated as "the factors to concern at classroom activity level" [L19, I1, p1] rather than at course level. Moreover, the influential levels of these factors were evaluated as "affecting the effectiveness of the classroom activities" rather than "formulating the teaching and assessment from the program to the course and activity levels" [L11, I3, p1]. In their beliefs, these factors were not also claimed as elements of classroom or school culture as being listed in Faour (2003), Bax (2003), Cuayahuitl and Carranza (2016), they were simple simply "affective factors" to teaching and learning; the culture of the school and class were noted as the vision, mission, values, educational philosophy of the university and the faculty where they were teaching. The extent to which a lecturer can take advantage of these factors and how he/she deals with them depend much on his/her pedagogical knowledge, skill, experience, and sensitivity level to context.

\subsection{How do these beliefs shape their actions when teaching in class?}

As being discussed in 4.1, each lecturer in the university adopts the institution's philosophy "Quality, sustainable development, international integration" as individual philosophy when teaching and working in the organization. As a result, similar to other lecturers in the university, the shared goals of the participants in this study is satisfying the stakeholders' needs at the present time and in the future and equipping the students the ability to work and study towards the current development trend and international demand of the workforce. Under this common goal, each of them developed a different set of most-favored ways of teaching and applied these ways in the courses they taught. In the interviews with the chosen participants, their stated most-favored and most-often-observed ways of teaching were:

Table 4: teachers' most-favored ways of teaching

\begin{tabular}{|l|l|}
\hline & \multicolumn{1}{|c|}{ Most-favored ways of teaching } \\
\hline $\begin{array}{l}\text { Lecturers } \\
6,7,19\end{array}$ & $\begin{array}{l}\text { Prepared students for various topics of translation } \\
\text { Give assignments to help develop self-study and continuous learning skills and attitudes } \\
\text { Incorporate new technology into translation activities }\end{array}$ \\
\hline $\begin{array}{l}\text { Lecturers } \\
15,22\end{array}$ & $\begin{array}{l}\text { Prepare students with unexpected translation contexts and requirements } \\
\text { Give assignments to help develop self-study and continuous learning skills and attitudes }\end{array}$ \\
\hline $\begin{array}{l}\text { Lecturers } \\
32\end{array}$ & Incorporate new technology into translation activities \\
\hline Lecturers & Give assignments to help develop self-study and continuous learning skills and attitudes \\
8,11 & Prepare students with different voices, accents, and levels of language proficiency \\
\hline
\end{tabular}

From their preferred ways of teaching, it can be inferred that, due to the teaching philosophy, the participant tented to prepare their students for a changing and diversifying rather than a fixed future. Moreover, the educational process seemed to focus more on active learning, exploratory and discovery than teaching and solely cognitive development, and the goal is not only personal development but also the development of society. All of these connotation meanings conveyed in the philosophy were performed obviously in the actions of the participants.

Interestingly, despites the differences in the way they expressed the personal missions, the participants who taught the same course, such as lecturers coded as L 7, 19, 22, 32 in the course Translation 2, shared quite similar set of actions when teaching and these actions aims at maximizing the achievement of the CLOs of the course they taught. When asked for the explanation why there was such a similarity, the participants confirmed that "we might have different statements, but we share the same goals of contribution to the achievement of the higher missions (mission of the faculty and university), and the same expected learning 
outcomes of the same course in a training program" [L19, I2, p2]. As a result, the roles that performed by the lecturers were not only limited to the roles of a teacher that recommended the literature of foreign language teaching such as controller, organizer, facilitators, resource, communicator (Brown, 2001; Leaman, 2008) but also the role of a quality controller at the course level. Under the common aims of achieving the CLOs, the lecturers played the fundamental role in facilitating students' achievement of CLOs, through integrated activities quality controlling and managing such as designing the course specifications, evaluating and choosing textbooks, developing rubrics for assessment, preparing teaching aid and materials, preparing lesson plans, teaching in classes, composing test questions, invigilating tests, scoring test papers, doing online and offline academic consultancy, organizing extra-curricular activities, preparing courses' portfolio and managing the course' LMS system, writing CLOs report, and participating in other professional development in quality assurance activities organized by the institution.

Although the participants admitted that other physical contexts of the classroom and psychological contexts of the students were inferior to the OBE factors in directing and shaping their actions, they also affirmed that quality of classroom activities was an important factor in determining gains in student achievement, and that improving student outcomes is also about improving the quality of the classroom activity level. In other words, improving classroom activity by controlling and managing the physical and psychological factors will help to create more effective teaching and learning environments for all students. Although the teaching contents and procedures must be standardized among lecturers teaching the same course to ensure the learning outcomes, there was also room for academic freedom in the university and the participants in this study often adopted the following strategies to solve teaching problems encountered in the classroom.

- Make minor modification on teaching materials: add, replace, remove, rearrange, re-design to deal with time constraint, proficiency level and motivation of the students.

- Change the organization of the classroom activities: pair, group, individual work, whole class lecture to make the organization fixed better to the classroom physical arrangement, the availability of the teaching aids and equipment.

- Vary the contexts of learning: Online platforms, offline, LMS, self-study to adapt the teaching to pandemic, give students more opportunities to develop self and more active learning skills.

It can be observed that beliefs about the physical and psychological factors served as a kind of interpretative framework through which they made sense of what they do in their classrooms. These beliefs were frames of reference around which many classroom decisions were made and pedagogical practices were adapted. Research on beliefs (Youngs \& Qian, 2013; Zhang, 2013) showed that teachers who possess clearly defined theoretical beliefs teach in a way that reflects these beliefs. Besides, Kumaravadivelu (2012) distinguished between core and peripheral beliefs. The former is more influential in shaping teachers' instructional approaches whereas the latter can cause divergence between what teachers claim they do and what they actually do in the classroom. Results of this study showed that the lecturers' beliefs and actions were closely matched. Any divergence between what teachers claimed they would do and what they actually did in the classroom was carried out only at classroom activity level and with a clear intention to deal with unexpected events or context of the classrooms. Lecturers' actions in terms of methods and strategies of teaching, management and assessment seemed to be consistent and standardized to ensure the expected learning outcomes of the course they taught.

\section{CONCLUSION}

In a teaching context where the outcomes were formulated and highly demanded by the stakeholders, language teachers' teaching beliefs were closely mapped to the educational culture of the context and their actions also clearly reflected what they believed. The strongest factors that shaped the teachers' beliefs and actions at course level were the teaching philosophy of the institution and the expected learning outcomes of the course they taught. Significantly, results from participants in this study showed that the contextual factors that previously-believed to significantly affect teachers' actions such as class size, motivation and proficiency level of students, course-book, syllabus, time, facilities, materials, and physical resources were much less influential than the expected outcomes of the course and the assessment. The teachers strongly believed that these physically and psychologically related factors were more influential at classroom activity level. Their planned actions were a result of the beliefs of the quality assurance concepts driven from OBE such as the educational philosophy of the university, the expected learning outcomes of training 
program; these sets of beliefs took the role of shaping their actions as a member working in the university and a teacher in planning, teaching and evaluating the outcomes of the course. Therefore, different form previous studies, two groups of beliefs were generated namely beliefs about contextual factors that formulate the teaching and beliefs about contextual factors that affect the teaching. Moreover, this study also found that when the contextual factors are defined under OBE framework, there were also new roles for a language teacher to be responsible for while teaching. Besides teaching, a teacher in an OBE system must also take part in the outcome formulation process of the program and the course, playing the role of a quality assurance manager at course level, and acting actively in personal range of duty to contribute to the achievement of the organizational objectives and missions.

Although the sample of this study was quite small, compared to previous researches in language teaching examining the effect of contextual factors, this study contextualized beliefs and actions of the teachers in an OBE context under quality assurance perspective. The results yielded findings that would be significant for program and course management and teacher training purposes within the university and other similar contexts. In fact, beliefs are episodic, affective have an adaptive function; beliefs can be changed or reoriented as a result of input from other professionals and activity type interventions. Therefore, under a particular outcome-based philosophy and practice with high demands form stakeholders and standardized procedures regulated by an international quality assurance framework, the language teachers' beliefs and actions are also highly contextualized. Further study might investigate larger group of participants and examine whether their beliefs and/or actions would evolve when there are changes in the requirements from the program's and course's stakeholders.

\section{REFERENCES}

Ajzen, I. (1991). The theory of planned behaviour. Organizational Behaviour and Human Decision Processes 50, $179-211$

Altınsoy, E., \& Okan, Z. (2017). The impact of contextual factors on English language teachers' beliefs. Journal of Language and Linguistic Studies, 13(2), 53-70.

Aune, B. (1990). Action, Inference, Belief, and Intention. Philosophical Perspectives 4, 247-271.

Bandura, A. (1997). Self-Efficacy: The exercise of control. W H Freeman/Times Books/ Henry Holt \& Co.

Barcelos, A. M. F. (2003). Researching beliefs about SLA: A critical review. In Kalaja, P. \& A. M. F. Barcelos. Beliefs about SLA. Kluwer Academic Publishers, 7-33.

Barkhuizen, G. P. (2008). A narrative approach to exploring context in language teaching. ELT Journal, 62 (3), 231 239.

Bax, S. (2003). The end of CLT: a context approach to language teaching. ELT Journal, 57(3), 278-287.

Biggs, J. (2014). Constructive alignment in university teaching. HERDSA Review of Higher Education, 1

Borg, M. (2001). Teachers' beliefs. ELT Journal, 55(2), 186-188.

Borg, S. (2006). Teacher cognition and language education. Continuum.

Borg, S. (2015). Teacher cognition and language education: Research and practice. London, UK: Bloomsbury.

Borsoto, L. D., et.al. (2014). Status of Implementation and Usefulness of Outcomes-Based Education in the Engineering Department of an Asian University. International Journal of Multidisciplinary Academic Research, 2(4), 14-25.

Brown, H. Douglas. (2001). Teaching by Principles: An Interactive Approach to Language Pedagogy. (2nd ed.). New York: Addison Wesley: Longman, Inc.

Cuayahuitl and Carranza (2015). Influence of Contextual Factors on EFL Mexican Teachers' Beliefs and the Use of Textbooks, $H O W, 22(2), 75-90$. 
OF EFL TEACHERS' BELIEFS AND ACTIONS

Davis, M. H. (2003). Outcome-based education. Journal of veterinary medical education, 30(3), 258-263.

Dobbins, Kerry, Brooks, Sara, Scott, Jon, Rawlinson, Mark \& Norman, Robert. (2016). Understanding and enacting learning outcomes: the academic's perspective. Studies in Higher Education, 41(7), 1217- 1235

Donaghue, H. (2003). An instrument to elicit teachers' beliefs and assumptions. ELT Journal, 57(4), 344-351.

Dufva, H. (2003). Beliefs in dialogue: a Bakhtinian view. In Kalaja, P. \& A. M. F. Barcelos. Beliefs about SLA. Kluwer Academic Publishers, 131-152.

Faour, B. (2003). Early childhood Teachers in Lebanon: Beliefs and practices. Ph. D theses. School of education. University of Leicester. UK.

Fives, H., \& Buehl, M. (2012). Spring cleaning for the "messy" construct of teachers' beliefs: what are they? which have been examined? What can they tell us? Educational Psychology Handbook, 2.

Gass, S. M. \& Mackey, A. (2000). Stimulated recall methodology in second language research. Lawrence Erlbaum Associates.

Glaser, B. G. \& Strauss, A. L. (2009). The discovery of grounded theory: strategies for qualitative research. Aldine Transaction, Transaction Publishers.

Golombek, P. R. (1998). A study of language teachers' personal practical knowledge. TESOL Quarterly, 32(3), 447464.

Haney, J. J., Andrew, T. L., Czerniak, C. M., \& Egan, V. (2002). From beliefs to actions: the beliefs and actions of teachers implementing change. Journal of Science Teacher Education, 13(3), 171-187.

Hồ, H. L. \& Nguyễn, T. H. (2018). Ba hướng tiếp cận trong định nghĩa năng lực. Tạp chí Khoa học Quản lý Giáo dục, 03(19).

Hsieh, H. \& Shannon, S. E. (2005). Three approaches to qualitative content analysis. Qualitative Health Research, 15(9), 1277-1288.

Jamalzadeh, M. and Shahsavar, Z. (2015). The Effects of contextual factors on teacher's beliefs and practices. Procedia - Social and Behavioral Sciences 192, 166 - 171.

Kalaja, P. (2003). Research on students' beliefs about SLA within a discursive approach. In Kalaja P. \& A. M. F. Barcelos. Beliefs about SLA. Kluwer Academic Publishers, 87-108.

Khoshsima, H. \& Toroujeni, S M H. (2017). Context in English Language Teaching Program: Differentiating between Iranian Public Schools and Private Institutes. JELTL, 2(1), 2017.

Kilfoil, W. R., \& Van der Walt, C. (1997). Learn 2 teach: English language teaching in a multilingual context. Pretoria: Van Schaik Academic.

Kramsch, C. (2003). Metaphor and the subjective construction of beliefs. In Kalaja P. \& A. M. F. Barcelos. Beliefs about SLA. Kluwer academic publishers, 109-128.

Kumaravadivelu, B. (2012). Language teacher education for a global society. New York: Routlege.

Leaman, Lousia. (2008). The Perfect Teacher: How to make the very best of your teaching skills. London: Continuum International Publishing Group.

Leont'ev, A. (1974). The problem of activity in psychology. Soviet Psychology, 13(2), 4-33.

Hang, M. Th. Nh. (2017). Contextual factors affecting the implementation of communicative language teaching in Vietnam. EFL JOURNAL, Volume 2(2), 2017 p.103-113 
Mak, S. H. (2011). Tensions between conflicting beliefs of an EFL teacher in teaching practices. RELC Journal, 42(1), 53-67.

Mohamed, N. (2006). An Exploratory Study of the Interplay between Teachers' Beliefs, Instructional Practices \& Professional Development. Unpublished Doctoral Thesis, The University of Auckland.

Malan, S. P. T. (2000). The 'new paradigm' of outcomes-based education in perspective. Journal of Family Ecology and Consumer Sciences/Tydskrifvir Gesinsekologie en Verbruikerswetenskappe, 28(1).

Norman, D. (1983). Some observations on mental models. In D. Gentner \& A. Stevens (Eds). Mental Models. Lawrence Erlbaum, 7-14.

Nespor, J. K. (1985). The role of beliefs in the practice of teaching. Research and Development Centre for Teacher Education, Texas University.

Ortega, R. A. A. and Cruz, R.A. O. (2016)., "Educators' Attitude towards Outcomes-Based Educational Approach in English Second Language Learning.” American Journal of Educational Research, vol. 4, no. 8 (2016): 597 601.

Peacock, M. (1998). Exploring the gap between teachers' and learners' beliefs about 'useful' activities for EFL. International Journal of Applied Linguistics, 8(2), 233-250.

Phillips, M. (2009). "Beginning teacher beliefs and wise practices: A case study of a high school social studies teacher". Ph.D dissertation, University of Florida.

Richards, J.C. \& Pennington, M. (1998). The first year of teaching. Cambridge: Cambridge University Press.

Sakui, K. (2004). Wearing two pairs of shoes: Language teaching in Japan. ELT Journal, 58 (2), 155-163.

Schlebusch, G., \& Thobedi, M. (2004). Outcomes-based education in the English second language classroom in South Africa. The qualitative report, 9(1), 35-48.

Schlebusch, G., \& Thobedi, M. (2005). Linking English first additional language teaching and learning with outcomes-based education: what is really happening? Journal for Language Teaching, 39(2), 306.

Seale, C. (2004). Research society and culture. Sage Publication.

Setyaningrum, T. (2018). Teachers' beliefs about communicative language teaching (CLT) and the implementation in classroom Practices. Jurnal Pendidikan Humaniora, 6(4), 152-161

Sin, C. (2014) Lost in translation: the meaning of learning outcomes across national and institutional policy contexts. Studies in Higher Education, 39(10)

Sun, Q. (2017). An exploratory study of Chinese university English-as-a-foreign-language (ELF) teachers' cognitions and practices about English grammar teaching: a thesis submitted in fulfillment of the requirements for the degree of doctor of philosophy (Ph.d.). The University of Auckland.

Tam, Maureen. (2014). Outcomes-based approach to quality assessment and curriculum improvement in higher education. Quality Assurance in Education, 22(2).

Wenden, A. L. (1986). Helping language learners think about learning. English Language Teaching Journal 40, 3-12.

Wenden, A. (1987). How to be a successful language learner: Insights and prescriptions from L2 learners. In A. Wenden \& J. Rubin (Eds.), Learner strategies in language learning. Englewood Cliffs, NJ: Prentice/Hall International, 103-118.

Williams, M. \& Burden, R. L. (1997). Psychology for language teachers: A social constructivist approach. Cambridge University Press.

(C) 2021 Industrial University of Ho Chi Minh 
Willis, S. \& Kissane, B. (1995). Outcome-based education: a review of the literature. Education Department of

Western Australia.

Woods, D. (1996). Teacher cognition in language teaching: beliefs, decision-making, and classroom practice. Cambridge University Press.

Youngs, P. and Qian, H. (2013). The influence of university courses and field experiences on Chinese elementary candidates' mathematical knowledge for teaching. Journal of Teacher Education, 64, 3:244-261.

Zhang, H. (2013). How was your weekend?: developing the interactional competence in managing routine inquiries. Language Awareness, 22(1), 67-78.

\section{TÁC ĐộNG CỦA TRIẾT LÝ GIÁO DỤC VÀ DẠY HỌC THEO CHUẨN ĐẦU RA LÊN NHẬN THỨC VÀ HÀNH VI CỦA GIÁO VIÊN GIẢNG DẠY TIẾNG ANH}

Tóm tắt. Bài nghiên cứu này có mục tiêu tìm hiểu niềm tin và hành vi của một nhóm giảng viên giảng dạy tiếng Anh trong môi trường giảng dạy mà ở đó các chuẩn đầu ra được xây dựng dựa trên yêu cầu từ các bên liên quan của chương trình đào tạo và việc dạy và học trong toàn hệ thống được vận hành theo nguyên tắt đảm bảo chuẩn đầu ra. Đối tượng nghiên cứu là nhóm 35 giảng viên dạy nhiều môn học khác nhau trong chương trình cử nhân Ngôn ngữ Anh đã được tổ chức đảm bảo chất lượng quốc tế AUN-QA đánh giá và công nhận. Các phương pháp khảo sát, quan sát, phỏng vấn khác nhau đã được thực hiện trong suốt quá trình giảng dạy môn học này. Phần mềm Microsoft Excel được dùng để phân tích phần dữ liệu định lượng, phần mềm NVIVO được sử dụng làm công cụ chính hỗ trợ phân tích dữ liệu định tính. Kết quả thu về cho thấy nghiên cứu đã tìm thấy một số kết quả mới và đáng chú ý so với những nghiên cứu trước đây liên quan đển niềm tin và hành vi của giảng viên giảng dạy Tiếng Anh trong môi trường đặt trưng này. Kết quả cho thấy giảng viên hình thành 2 nhóm niềm tin (1) về những yếu tố quyết định đến toàn bộ quá trình giảng dạy và (2) những yếu tố chỉ ảnh hưởng đến quá trình triển khai các hoạt động cụ thể trên lớp học; 2 yếu tố giữ vai trò quyết định đến giảng viên trong quá trình giảng dạy là triết lý giáo dục tại cơ sở đào tạo và chuẩn đầu ra môn học. Kết quả còn cho thấy ngoài công tác giảng dạy thông thường, người giảng viên còn đảm nhận cả vai trò như một người kiểm soát về chất lượng và mức độ đạt được chuẩn đầu ra môn học cũng như đóng góp vào việc hoàn thành các mục tiêu chiến lược về đào tạo của cơ sở giáo dục.

Từ khóa: dạy học theo chuẩn đầu ra, nhận thức và hành vi của giảng viên

\section{APPENDIX \\ The questionnaire for surveying at the beginning of the course}

1. What are the strengths of the graduates from the program you are teaching compared to other similar programs in your country? [there was more space in the distributed questionnaire]

2. What are your contributions in shaping these strengths?

3. What are the most influential factors that shape and direct your teaching?

4. Among the following factors, please choose the factors that you believe to influence you STRONGLY while teaching?

$\square$ The available facilities and teaching aids

$\square$ Learners' levels of proficiency

$\square$ Time constraint

$\square$ Learners' psychological factors such as motivation, attitude, styles

$\square$ Course's expected learning outcomes (CLO)

$\square$ Program's expected learning outcomes (PLO)

$\square$ Testing and assessment 
$\square$ The educational philosophy of the university

$\square$ The personal educational philosophy of the teacher

$\square$ Other factors

Please evaluate the influential level of the following factors?

5. The available facilities and teaching aids

$\begin{array}{lllllllll}1 \text { (very low) } & 2 & 3 & 4 & 5 & 6 & 7 \text { (very high) }\end{array}$

6. Learners' levels of proficiency

7. Time constraint

$\begin{array}{lllllll}1 \text { (very low) } & 2 & 3 & 4 & 5 & 6 & 7 \text { (very high) }\end{array}$

$\begin{array}{lllllll}1 \text { (very low) } & 2 & 3 & 4 & 5 & 6 & 7 \text { (very high) }\end{array}$

8. Learners' psychological factors such as motivation, attitude, styles

$\begin{array}{llllllll}1 \text { (very low) } & 2 & 3 & 4 & 5 & 6 & 7 \text { (very high) }\end{array}$

9. Course's expected learning outcomes (CLO)

$\begin{array}{llllllll}1 \text { (verylow) } & 2 & 3 & 4 & 5 & 6 & 7 \text { (very high) }\end{array}$

10. Program's expected learning outcomes (PLO)

11. Testing and assessment

$\begin{array}{llllllll}1 \text { (very low) } & 2 & 3 & 4 & 5 & 6 & 7 \text { (very high) }\end{array}$

12. The educational philosophy of the university

$\begin{array}{llllllll}1 \text { (very low) } & 2 & 3 & 4 & 5 & 6 & 7 \text { (very high) }\end{array}$

13. The personal educational philosophy of the teacher

14. Other factors

$\begin{array}{llllllll}1 \text { (very low) } & 2 & 3 & 4 & 5 & 6 & 7 \text { (very high) }\end{array}$

$\begin{array}{lllllll}1 \text { (very low) } & 2 & 3 & 4 & 5 & 6 & 7 \text { (very high) }\end{array}$

15. Do you have any personal goals and values while teaching? If yes, what are they and why?

16. What are your favorite teaching methods? Why?

17. What are the factors that shape your teaching methods? Why?

18. What are your roles while working in this university? Why do you believe so?

If it is possible, would you please give me your contact in case I think we need further interviewing Thank you

Received on: 11/03/2021

Accepted on: 01/05/2021 